\title{
Pesantren Responses to Religious Tolerance, Pluralism and Democracy in Indonesia
}

\author{
Nurrohman ${ }^{1}$ \\ ${ }^{1}$ Faculty of Sharia and Law, Sunan Gunung Djati State Islamic University, Bandung Indonesia. \\ Email:nsyarif2006@yahoo.co.id
}

\begin{abstract}
Pesantren (Islamic boarding school) is the oldest Islamic institution in Indonesia that often affiliated to the largest mass Muslim organization Nahdlatul Ulama. This organization is well known for its stance to uphold moderate, tolerance Islam and accepting pluralistic state based on Pancasila. Pesantren also often referred as the barometer to understand the way of thinking of Muslims grass root in Indonesia because many Islamic figures in Indonesian village are alumni of pesantren.
\end{abstract}

There are debates among scholars on whether religious violence has a root in religious doctrine or it is caused by factors outside religion such as poverty or injustice. By assuming that both inside and outside factors have significant contribution to violence or radicalism this study will discuss the doctrine that potentially can be used to justify violence and intolerance by reviewing the opinion of pesantren leaders in West Java on jihad, violence or intolerance and power. This study is aimed to examine whether the commitment of Muslim leaders in national level on democracy and plurality is supported by grass root particularly from pesantren leaders.

Overall the study found that although they agree that democracy is compatible with Islam, this study reveals that their acceptance to pluralism still be questioned as evidenced by almost half of them supported theocratic caliphate carry out by radical group.

Although many argued that pesantren promotes tolerance and pluralism, nevertheless this study shows that some of their teaching tacitly supported violence act in the name of religion that will tarnished the effort of Indonesia to synchronize Islam, democracy and modernity. It means that many of them actually not wholeheartedly accepted democracy and pluralism.

Keywords: radical Islam, Islamic state, democracy.

\section{A. INTRODUCTION}

Indonesia often praised as a country that their Muslim population embraced moderate and tolerance face of Islam in which Islam can thrive together with democracy and modernity (Clinton, 2009). But strangely when religious intolerances and violence acts using religious nuance occurred, the majority of Muslims are silent. Of course it raises some questions whether they are tolerating this act, whether their tolerance to violence actually has a root in their teaching and doctrine? Whether they are accepted democracy whole-heartedly?

Pesantren (Islamic boarding school) is the oldest Islamic institution in Indonesia (Karel A. Steenbrink, 1986). That often affiliated to the largest mass Muslim organization Nahdlatul Ulama. This organization is well known for its stance to uphold moderate, tolerance Islam and accepting pluralistic state based on Pancasila. Pesantren also often referred as the barometer to understand the way of thinking of Muslims grass root in Indonesia because many Islamic figures in Indonesian 
village are alumni of pesantren (Nurrohman \& Zulkarnain, 2007).

Radical Islam movement always has connection with the way they embrace the meaning of jihad particularly in order to combat vices (munkar) or what they called the situation of injustice. Radical Islam also always close to practical politics in the sense gaining, defending or destroying political power deemed as an obstacle to their own political agenda. In order to pursue power or establish Islamic state, they no hesitate to use violence and criminal acts (Abas, 2006).

Historically, West Java is one of the regions that ever used as the base of struggle to hold power and establish Islamic state (C.Van Dijk, 1987). Preliminary survey indicates that some of pesantren (Islamic boarding schools) in West Java has a potential to be used for the basis of the growing movement allowing violent act. The early research also reveals that Jamaah Islamiyah (JI), Islamic hardliners group striving to build caliphate (khilafat) in South East Asia also use pesantren as the basis to instill their political ideology.

The latest report from International Crisis Group (ICG) in Brussels entitle: Jamaah Islamiyah's Current Status, reveals that JI still harbor an idea to establish Islamic State in Indonesia. This report also mentions that the power of $\mathrm{Jl}$ in various areas in Indonesia will be determined by some factors such as pesantren affiliation with $\mathrm{Jl}$, the history of Dar al-Islam in this region, business and family relationship among their member, their success in recruiting cadres from campus and the recruitment process occurred within the prison (www.crisisgroup.org).

There are many factors can drag somebody to become radical, such as education, economics, environment including political ideology which developed in his or her milieu. Not all of these factors be searched and investigated, this research focused only on the religious views mirrored on the views of religious leaders in this case pesantren leaders.

There are debates among scholars on whether religious violence has a root in religious doctrine or it is caused by factors outside religion such as poverty or injustice. By assuming that both inside and outside factors have significant contribution to violence or radicalism this study will discuss the doctrine that potentially can be used to justify violence, intolerance or radicalism by reviewing the opinion of pesantren leaders on jihad, violence or intolerance and power. This study is aimed to examine whether the commitment of Muslim leaders at national level to promotes pluralism is supported by grass root particularly from pesantren leaders.

The amount of pesantren in West Java according to data from EMIS (Education Management Information System) is 6.930. The population of pesantren in five locations in which research has been conducted are 1459 consisted; Cirebon 397, Indramayu 56, Majalengka 323, Kuningan 430, and Ciamis including Pangandaran 353. Not all of them are surveyed or investigated. After being separated based on the types of pesantren (traditional, modern and semi modern) only some 20 pesantren represents the three types of pesantren in each region are randomly picked. So the total amount of pesantren used as sample is some 100 pesantren.

\section{B. METHODOLOGY}

Data will be analyzed based on discourse on political power, sharia law and Islamic state among Muslims as well as discourse on religious tolerance and pluralism. It is hypothesized that some of pesantren in West Java still promoting the religious teaching that can be viewed as a form of legitimacy to use violence or in accordance with political idea of Islamic radical groups. This research based on assumption that the more Muslims give their support for certain Islamic 
teaching legitimizing the use of violence, the more violence will happen. This research also based on assumption the more Muslims give support to political ideology of radical group, the future of Pancasila ideology and democracy in Indonesia are in danger.

\section{RESULT AND DISCUSSION}

\section{On jihad and terrorism}

Concerning jihad and terrorism, this research finds that most Pesantren in West Java not agree to equate jihad with war or other violence act. Almost all (99\%) of pesantren leaders realize the most important problems faced by Muslims are stupidy, poverty and backwardness. Therefore jihadul akbar or jihad as a spiritual struggle against selfish desire, greed and lust for power is more important than jihadul asghar ( waging a war). However an ambivalence attitude was revealed by some pesantren leaders in dealing with Osama bin Laden. The worrying attitude is, there are pesantren leaders who still agree to what was done by Amrozi cs and acknowledged it as part of jihad. There are also a tendency among pesantren leaders to support a group of Muslims or state that accumulate weapon to face the enemy of Islam. One of the perceived enemies of Muslim is United States, particularly its interventionist policies.

\section{On violence and intolerance}

Many pesantren leaders condoned the emergence of vigilante groups that taking the law by their own hand in order to eradicate vices. They are condoned violence acts perpetrated by hard line groups such as Islamic Defender Front (FPI). This research finds that Muslims commonly still sensitive to speechs or expressions deemed an insult to Islam. They are supported the notion to give harsh punishment to everyone that they deem blasphemy to Islam.

Potential conflict between Muslim and non Muslim is still high since many pesantren leaders think it is impossible to built peace coexistence eternally with non Muslims or infidels.

The significant amount of them of them not ready to live in peace with Muslims sects considered deviant and blasphemy to orthodox tenet.

The resistance of pesantren leaders toward church very high as indicated by their support to Muslims who refuse to give permit for Church building in their area. Even just said happy Christmas is not allowed by many of pesantren leaders.

Concerning domestic violence, such as beating wife or children, many pesantren leaders still see it as an act legitimized by religion. Corporal punishment that has been abolished in more civilized country is still believed by some pesantren leaders as something appropriate for current time.

Acts that in international community had been categorized as violence against women, such as female circumcise, still supported by large amount of pesantren leaders for religious reason, although the Indonesian ministry of health has released circular prohibiting paramedic to serve this practice.

Discriminative attitude also exposed by some of pesantren leaders, when they also refused woman and non-Muslim to become head of state of Indonesia. 


\section{On political power and Islamic state}

Concerning the relation between religion and power, Islam and state this research finds that most pesantren leaders embraced an opinion that Muhammad PBH (peace be upon him) is not only a prophet or religious leader but also a head of state. Most pesantren leaders supported an opinion that Islam is religion and state (al-din wa dawlah) Therefore Muslim not only encourage to build the unity of political leadership in the world level by establishing the caliphate system but also should become a member of the political party based on Islam.

On Islamic state, although most of them agree to call Indonesia Islamic state and therefore to make Indonesia an Islamic state no more needed, most of them supported the effort to include Jakarta Carter as part of the Indonesian constitution as well as sharia inspired bylaw. However, their support to Pancasila state and NKRI is very high.

\section{Discussion and analysis}

\section{Does sharia really need Islamic state?}

All Muslims likely agree to made the prophet Muhammad as the role model of them (uswatun hasanah) (QS 33: 21), so it is understood if all of his livelihood be used as a source of inspiration for them. All Muslims also acknowledged that Muhammad is a moral and spiritual leader. This acknowledgment is strengthened by Qur'an (innaka la'ala khuluqin azim) (QS 68:4) and the saying of the prophet himself "I am asked to improve good morality". Therefore from the beginning, there is no indication that the prophet Muhammad has a target to become a holder of worldly power or political leader. If this is what he wishes, it can be achieved when he still in Mecca, as long as he ready to halt his message (Khan, 1987).

It is true, after he migrated to Medina, he trusted to be a leader of pluralistic society that can be called a state. Therefore it is not wrong if W. Montgomery Watt called Muhammad a prophet as well as statesman (Watt, 1961). But this position not acquired through direct injunction from Qur'an. There is no single verse in Qur'an that directly asks the prophet to establish a political power or state. After viewing that there is no verses that boldly obliged Muhammad to establish government, Ali Abd al-Raziq, one of the noted ulema form al-Al-Azhar in the early twentieth century, stated that building government or state is not part of the task that is revealed by God to the prophet Muhammad (al-Raziq, 1985). On other words the political position trusted to the prophet, because of his ability to preserve his high morality.

The similar opinion is also adopted by Asghar Ali Engineer when he asked by reporter of Tempo magazine. Qur'an not talking about state, he said. It only talks about society. In society we should enforced justice, forbidden to exploitation, not allowed to persecution. Qur'an is a book of moral guidance, how we can maintain our attitude, how to minimalize conflict. All eventually will gave benefit to livelihood in state, Asghar Ali added (Tempo magazine, 2008).

What it means? It means that the readiness of Muhammad SAW to become "head of state" is based on his ijtihad or individual reasoning at that time. I think, it is the reason, why when the prophet trusted to be a leader of pluralistic society, he ask all parts of community in Medina to make consensus that later well known by mithaq Madina or Medina Constitution. Constitution is then used by the prophet Muhammad to manage pluralistic society. So, it is understood, if not all Muslims agree to establish political power in the form of state. 
When Sunni scholars in classical period anonymously agree to establish caliphate their reference is "consensus" (ijma) of companions after the passing of prophet. That is why, not all Islamic scholars in classical period agree with this opinion. Abu Bakar Al-Asham from Mu'tazily sect, for instance, said that establishing caliphate is not mandatory for Muslims. The most important one for Muslims is performing sharia. As long as Muslims not hampered to perform their sharia norms, there is no need to establish political power or what is called Islamic state (Nurrohman, 2007).

In other words, the need to establish a state actually to assure the freedom of religion in which there is no single person that can be barred to conduct their religious belief and rite, as well as to protect and enforce social justice for all. It is the principle of social justice for all that was exemplified by the prophet Muhammad through Medina constitution.

According to Harun Nasution, there are at least eight principles adopted by Medina Constitution : 1) monotheism 2) unity and togetherness 3 ) equality and justice 4) religious freedom 5) defending state 6) preserving good tradition 7) supremacy of sharia 8) the politics of peace and protection. These principles are not so difference with principle adopted be UUD 1945, Indonesia's Constitution.

The principle of monotheism is mentioned in article 22,23,42,47 in Medina Charter, it also mentioned in the first principle of Pancasila, article 9 and 29 of UUD 1945. The principle of unity and togetherness is mentioned in article 1,15,17,25 and 37 of Medina constitution as well as mentioned in the third principle of Pancasila, article 1 verse 1, article 35 and 36 of UUD1945. The principle of equality and justice is mentioned in article 13,15,16,22,24,37 and 40 of Medina Constitution. It also mentioned in the fifth principle of Pancasila, article 27,31,33 and 34 of Indonesia's constitution.

The principle of defending state is mentioned in article $24,37,38$ and 44 of Medina constitution. It also mentioned in article 30 of Indonesia's constitution. The principle of preserving good tradition is mentioned in article 2 until 10 of Medina constitution. It also mentioned in article 32 Indonesia's constitution.

The principle of supremacy of sharia is mentioned in article 23 and 42 of Medina charter.(The disputes are ruled based Allah rules and the judgment of Muhammad SAW) This principle is not explicitly mentioned in Indonesia's constitution, but religious norms was adopted as logical consequence of implementing the first principle of Pancasila and article 29 of Indonesia's constitution.

The principle of politics of peace and protection is mentioned in article $15,17,36,37,40,41,47$ (peace and internal protection) as well as in article 45 (peace and external protection) of Median constitution. In Indonesia's constitution, this principle mentioned in preamble, article 11and 13 (Nasution, 1985).

Munawir Sjadzali, in his book Islam and Government (Islam dan Tata Negara) mentioned that the foundations laid down by Medina Charter as the basis of state for the plural society in Medina are: 1) all Muslims although from different ethnic or tribe are one community 2) the relationship between Muslims community and others is based on principles (a) good neighboring (b) to help each other in facing common enemy (c) defending who are persecuted (d) giving advice to each other and (e) respecting religious freedom. In addition, Munawir said that Medina charter that often called by many political scholars as the first constitution of Islamic state not mentions state religion (Sjadzali, 1990). 
So, if compared between Indonesia's constitution and Medina constitution, there is no significant difference except in wording.

So, when NU accepted pluralistic state based Pancasila as the final political ideal for Indonesian Muslim, it is actually based on strong arguments. This acceptance should be followed by its implications, including not demanding to revive Jakarta Charter. The fact, that more than half of pesantren leaders still have an "imagination" to insert Jakarta Charter to Indonesian constitution is an indication that the pluralistic attitude taken by elite $\mathrm{NU}$ is not really understood by their grass root or it is evidence that ideology of radical movement has infiltrated to pesantren. The height of support for caliphate system indicates that they are not wholeheartedly supporting Pancasila state as the final state for Muslims. In other word Pancasila state is only a middle target before Muslims have the power to establish political leadership in the world level by reviving caliphate system.

Implementing sharia actually not depend on Islamic state. Because there are many models that can be picked by Muslims to perform their religious rite and activity. At least there are three models that can be used to assess the application of sharia in one region; exclusive, inclusive and mixed or combination. The first model tried to implement sharia such as it is mentioned literally in the text of holy books. This model is based on assumption that sharia is a complete norms for Muslim covering all aspect of life. After the death of prophet Muhammad, sharia no more experience a process of evolution. Therefore, Muslims just implement it, if there is a clear formulation in the text of Qur'an or Hadits. If there is no clear norm in it, Muslims can use analogy Iqiyas or individual reasoning/ ijtihad. There is no need to adopt a system outside "Islamic system". Sharia is a God law that cannot be understood its goal precisely by human except Jurists or Mujtahid. Therefore, each legislation arranged by legislative body should be approved by sharia experts who had the right to assess and veto if they believe it contradict to sharia. Supporters of this model commonly embraced Receptie in complexu theory (LWC van den Berg). According to Juhaya S Praja, this theory comprises of three elements: 1) Islamic law can be imposed to Muslims in Indonesia 2) Muslims should embrace Islamic teaching 3) Islamic law is effective universally covering economics, penal or criminal law and private or family law (Praja, 2009).

The second model tried to implement sharia by seeing the concept or the purpose of sharia. If the main purpose of sharia has been captured, its implementation can be flexibel, able to accomadate traditions or outside resources. This model is based on assumption that each norms in sharia has its own reasoning and purpose. Therefore the proponents of this model not objected if sharia experinces a process of evolution. They are relatively easy to accept whatever system of law as long as this system adopted the principle of justice, equality, freedom, brotherhood and humanity. They able to accept system that protect five purposes defined by some Islamic scholars well known by maqashid al-shari'ah such as religion (al-din) a freedom of thinking (aql), offspring or heredity (nasl), property (mal) and the soul (al-nafs). In this model, sharia can be implemented openly. It means in applying sharia, local tradition and opinions derived from outside can be adopted. Sharia can be called an open system because it can be interpreted by a common person. There is no monopoly in interpreting sharia therefore the existence of the "super body" who monitored and monopolized its interpretation no more needed. The role of sharia expert is only giving fatwa (non binding legal opinion). Supporters of this model commonly used Receptie theory to explain the transformation of sharia law in Indonesia.

This theory developed by Snock Hurgronje in the late of nineteenth century. This theory said that for the indigenous people the law applied to them is customary law. Islamic law can be applied only if it has been accommodated in customary law (Praja). This theory based on assumption that not all Islamic law that originally from "Arab" is suitable to Indonesia therefore local or customary 
agent has the right to select and chose what element of Islamic law that suitable or not suitable for them. This causes plurality among Muslims or what Azyumardi Azra calls cultural pluralism (Azra, 2010).

The third model tries to combine both of two models. Regarding sharia norms that can be categorized as private or civil law they tend to use exlusive model, while on sharia norms that can be categorized as public matter, they tend to use inclusive one. Indonesia adopted mixed model of sharia implementation by using the maslaha theory as the grand theory and using a mixed between Receptie in Complexu and Receptie theory as an application theory. History shows that the model chosed by Indonesia is influenced by the politics of law (http://www.badilag.net) or the interconnection between law and politics (Daniel S. Lev, 1990).

In line with pluralistic model of sharia implementation, when Muslims countries declared their independence from colonialism and intended to establish modern state complete with its written constitution, there are many forms of constitution. Because, there aren't any exact model of government in Islamic teaching. At least there are four types of constitution. The first is state that its constitution recognized Islam as a state religion and placed sharia as a primary source in drafting legislation such as Saudi Arabia, Iran and Pakistan.

Secondly, state that its constitution denote Islam as state religion but not mentioned sharia as a primary source of legislation. It means that sharia treated only as one source of many sources used to make legislation such as Malaysia (Mahmood, 1987). The third, state that not made Islam as a state religion and also not mentioned sharia as a primary resource in formulating legislation but acknowledged sharia as a living law in society and considered it as one of many source in drafting legislation such as Indonesia. The fourth, state that declared itself as secular state and try to make sharia not influenced its legal system such as Turkey (Nurrohman, 2007).

In Indonesian history, discource on the position of sharia in constitution, at least has been discussed five times in parliament ; at the Council and Committee for Independent Preparation (BPUPKI-PPKI) in 1945, the Council of Constituante in 1956-1959, Temporary of People Consultative Assembly (MPRS) in 1966-1968, annual meeting of People Consultative Assembly (MPR) in 2000, and annual meeting of MPR in 2001.

Each time, when sharia will be formally included in Indonesian constitution, it always invited pros an cons. The proponents of formalization of sharia, commonly argue that since the majority of Indonesian is Muslims, so it is understood if the law imposed in Indonesia particularly for Muslims is sharia. Secondly, the assurence of sharia in constitution actually part of gentlement agreement of founding fathers expressed by their acceptence to Jakarta Charter (Piagam Jakarta). This charter is a compromise choice between secular and Islamic state. Thirdly, the formalization of sharia not affected non Muslim because sharia law will gave blessing to humankind.

The opponent of sharia formalization in constitution exposed arguments, among other ; firstly, the inclusion of seven words of Piagam Jakarta will pave the way of state intervention in religious domain that evantually will affect religion as well as public domain. Secondly, the inclusion of seven words of Piagam Jakarta will raises old prejudice from non Muslim on Islamic state in Indonesia. Thirdly, the inclusion of Piagam Jakarta also contradict with national system that treated all group in society as equal citizen, including religious groups (Zein, 2001).

The opponent of sharia formalization also presented reason about the possiblity of nation disintegration because people who reside in eastern part of Indonesia threatened to separate from 
Unitary State of Indonesia if sharia law inserted in constitution.

In the other side, the proponent of sharia formalization blamed government for their reluctant to accomodate sharia law. This reluctant caused the emergence of dissatisfaction that manifested in Darul Islam rebellion. Firdaus AN one of Islamic figure that actively engage in various Islamic mass organization, for instance, regretted the omitting of seven words which according to him triggered the emergence of rebellion in many regions. Begining with Darul islam lead by Kartosuwiryo in West Java (9 August 7,1949), then continued by Kahar Muzakar in South Sulawesi (1952), Daud Beureuh in Aceh ( 1953) and Ibn Hajar in South Kalimantan (1953) (Zein, 1987).

How strong the argument used by radical group to justify violence?

Although the term jihad actually has many meanings, radical movement who used Islam as political ideology prefers to use its violence meaning. In defending their preference, they have similar arguments upheld by supporters of exclusive and literal model of sharia implementation. The main arguments used by exclusivists are: 1) sharia is a complete norm for Muslim covering all aspect of life, so there is no need to adopt a system other than"Islamic system". Therefore good Muslims will adopt sharia totally (kaffah) 2) sharia is not experience a process of evolution. Therefore the development of age should be adjusted to a system of Islam that has been practized in the past not vice versa 3) Since sharia is God law, that cannot be understood by common person, it need special body comprised of sharia experts or fuqaha who had the right to veto a bill if they believe it is contradict to sharia.

The first argument "sharia is a complete norms for Muslim covering all aspect of life" is clearly exposed by Suryani, a plaintiff of judicial review, who see that the implementation of jinayat punishment is a part of the effort to make Muslims completely conducting their duty in implementing sharia (verdict of Constitutional Court, 2008). For him, Muslims as community not able to be called embracing Islam in totality (kaffah) yet if they cannot apply jinayat sanction such cutting hand off the theft. When Suryani requested a review on article 49 verse (1) of Islamic court law, he clearly presented the verse 38 of al-Maidah, which according to him, literally, asked Muslims to cut the hand off the theft. Islam kaffah is originally derived from the words al-silmi kaffah in the verse 208-chapter al-Baqarah in the Qur'an. While al-silmi has other meaning such as peace, Suryani prefer to pick Islam or precisely sharia as it's meaning. So, the mean of Islam kaffah according to him is embracing sharia law, not only in private or civil matter but also in public matter literally. The argument picked by Suryani, commonly, used by groups of Muslims that see Islam as exclusive religion.

The second argument "sharia is not experience a process of evolution" is also clearly used by both Suryani as well as Ja'far Umar Thalib when the later imposed rajam penalty in Ambon to it member because of adultery. Both believed that the punishment of a marriage adulterer is rajam and the punishment of the theft is cutting off his or her hand. It means that sharia norm particularly that regulates punishment of crime not experience evolution or change. This belief differs from other Islamic scholars who divided sharia broadly into two; ibadah (something related to ritual activities) and mu'amalah (something related to human to human relation). Many scholars believe that sharia on ritual activity not experience change, while sharia on human to human relation can experience change in line with the dynamic of human civilization. Slavery is a glare example that although it is clearly mentioned in sharia, almost all Muslim scholars in this day agree to abolish it. 
The third argument is based on assumption that sharia is God law, that cannot be understood by lay person, therefore it need special body comprised of sharia experts or fuqaha who had the right to veto a bill "contradicts" to sharia. This assumption is clearly exposed by Ja'far Umar Thalib when he and his Laskar Jihad sought after back up from Ulema. According to Ja'far, rajam punishment in Ambon is preceded by declaration approved by some of Islamic figures to maintain security and upholding sharia. When the blessing or permission from Ulema placed above the existing legal system of Indonesia, it means that Ulema likely have the veto right to abandon the existing laws or regulations that they deemed contradict to sharia. This stance is, of course, challenged by other Islamic scholars.

In commenting rajam case in Ambon, KH Umar Shihab, one of the chairman of Indonesian Ulema Council (MUI), said : "Implementing sharia law should follow the mechanism of legal system legitimazed by the state". Umar Shihab argues that according to Qur'an, who asked to enforce law is government or the holder of power. "Sharia law should be based on what is approved" He added. Similar comment also presented by Prof.Drs.Asmuni Abdurrahman from State Islamic Institute (IAIN) Sunan Kalijaga, Yogyakarta.

According to Asmuni, in implementing sharia law, the rule of game should be clear. "The government should be Islamic government, the adulterer or the perpetrator shuold be processed and ruled by the council of jugdes". Asmuni said to Sukoco from Gatra magazine. Prof. Dr. Syechul Hadi Pernomo, Islamic law scholar from IAIN Sunan Ampel, Surabaya, tries to offer solution. "If they want to have autonomy in legal affairs, at least there should be a region and waliyul amri (government)," he said. That is why Syechul advised, if Islamic law want to be implemented it should be collaborated to KUHP (Penal Code) that currently accepted as positive law for Indonesia (http://www.oocities.com).

In explaining why religion can resort to violence, Din Syamsuddin, chairman of Muhammadiyah, said that religion, including Islam, can serve as an integrative force paving the way to peace, dialogue and cooperation, but in another time it can also be disintegrative one leading to conflict, violence and war.

The disintegrative force of religion manifests itself in at least three characteristics of religion, which always appear in the consciousness of the believers. Firstly, religion brings about absolutism. This becomes a consequential outcome of personal and subjective belief toward the Absolute Being or God. Absolutism is often followed by rejection attitude against other faiths. In many cases, absolutism becomes a root cause for fanaticism, exclusivism and extremism, which encourage conflict in both intra and extra levels of a religious community.

Secondly, religions teach expansionism, that is, a doctrine on the obligation of the believers to spread their belief to other people. The history of religions bears witness to the fact that all religions expanded out of their birth places. Expansionism, which has ideological legitimacy from the Holy Scriptures, is believed as a sacred mission to be undertaken. The problem starts to occur when the mission is undertaken by each religious group against the other. An inevitable interaction thus arises and becomes a driving factor for tension and conflict.

Thirdly, religion also has a penetrative tendency into non-theological areas, such as social, politics, economy and culture. This penetration, which takes the form of acculturation between religion and culture, may proceed in two possible ways: absorption of religion into culture or absorption of culture into religion. The interaction between two realms, each has its own defenders, has stimulated religious conflict with a cultural dimension, or cultural conflict with a religious dimension 
in the life of the society. Religious conflict is, thus, multi-dimensional in nature; it is true that it has a theological dimension, but it cannot be ignored that it also included socio-economic, political and cultural dimensions. These non-theological factors, sometimes, become primary reasons for conflict and cooperation as well.

Those three characteristics above have prevented religionists to realize the moral and ethical values of religions, such as love, mercy, tolerance and understanding, in the making of peaceful coexistence, dialogue and cooperation. Religions have an ambivalent tendency toward dialogue, cooperation and peace. If it is seen from sociological and horizontal perspective, religions have two forces: integrative force and disintegrative force. In this context, religions could create close and cohesive unity, peace and cooperation, but at the same time they could also bring disunity, tension and conflict (Syamsuddin , 2006).

With this long explanation, Din Syamsuddin likely said that when religion was mixed with other interest such as politics and economics, it is difficult to make it as unifying factor.

Similar to what is said by Din Syamsuddin, Asghar Ali Engineer when asked about the possibility to make all Muslims as one political power, said that Muslims able to be united as one community only on religious matters not on political matters. We are speak in difference language, have difference culture, using different clothing. The only factor that unified us is the sameness of our religion. Muslims are never becoming a political unity from the start until now. Each state and ruler has different interest. Egypt, Syria and Libya ever joined to be one nation; United Arab Republic but its age only two years. Pakistan and Bangladesh eventually separated. Indonesia and Malaysia cannot be united (Tempo magazine, 2008). It means that effort of some radical movement to establish caliphate is an illusion viewed from historical experience (Wahid, 2009).

So, from the above explanation, radical group actually used disintegrative force of religion, term used by Din Syamsuddin, by exploiting its absolutism, expansionism and its penetrative tendency to non- theological area.

\section{Why pluralism and religious tolerance difficult to be accepted by some Muslims?}

In my opinion there are many factors that caused some Muslims difficult to accept pluralism and tolerance.

The first related to concept of hifzu al-din (protection of religion) in Islamic law. This concept actually should be used to protect someone in performing religion conviction and religious obligation. In Qur'an there is a guaranty that there is no coercion in religion (QS 2; 256), for you your religion and for us our religion (QS 109: 6). But some Islamic scholars still uphold the opinion that someone who convert from Islam to other religion or someone who blaspheme Islamic religion can be considered apostate. And the punishment for apostasy, in classical Islamic law, is to be killed. Therefore it can be understood that following the issuance of the verdict, said that Ahmadiyah is heretical sect and it followers are apostate (murtad) some hard-line groups declared the blood of the Ahmadiyah congregation halal (permissible).

Secondly related to the concept of nahi munkar (preventing something considered bad) derived from the prophet tradition. The prophet said whoever sees something considered bad please change it with their own hand. While it is correct to change something bad in society, the hardliners among Muslims often translated or replaced the word to change with to destroy. Admittedly it is difficult and need more effort, strive and patient to change something without 
destroying it. It needs deep study to understand factors caused it and the interrelation between one factor with another. When some hardliners in Bandung eager to close and destroy Saritem area ( place notoriously used by prostitute to serve their clients) KH Imam Sonhaji, chief of lawmaker body in Bandung NU district, for instance, instead, choose to establish Daar al-Taubah boarding schools in this location and approached them peacefully. What is Sonhaji done is an example of changing without destroying.

The third is the concept of annulment (nasah mansuh). This concept based on assumption that there are many verses in Qur'an that contradict each other. To overcome this problem some scholars said that the verse revealed earlier should be cancelled by the verse received later (Abdullahi Ahmed an-Na'im, 1990). As a consequence, verses encourage pluralism and tolerance according to some scholars, had been cancelled. Assessing that verses strengthened pluralism and tolerance had been cancelled was equivalent to ignoring part of the verses of Qur'an that actually can be used as proposition to develop religious pluralism and tolerance.

The fourth is the lack of law enforcement from the law officers in Indonesia. In many cases it is the victims not the attackers who arrested and investigated by police. Actually it is the right of MUI to issue the fatwa (edict) said that religious teachings influenced by pluralism, liberalism and secularism are against Islam. It is the right of MUI to said that Muslims must consider their religion to be the true, and consider other faiths as wrong. In democratic society, it is the right to someone to say that Ahmadiyah, an Islamic group that does not recognize Muhammad as the last prophet, is a heretical sect, and its followers are murtad (apostate). But when the hardliners used this edict to attack them physically it is the duty of police to prevent it.

The fifth is the lack of education among Muslims as result of poverty. It should be acknowledged that religious violence in many cases often related to political conflict or political interest. Some persons used religious symbol as political commodity to gain power but it is difficult politicize religion if Indonsian Muslims more smart and prosper.

\section{CONCLUSION}

Pesantren (Islamic boarding school) is the oldest Islamic institution in Indonesia that often affiliated to the largest mass Muslim organization Nahdlatul Ulama. This organization is well known for its stance to uphold moderate, tolerance Islam and accepting pluralistic state based on Pancasila. Pesantren also often referred as the barometer to understand the way of thinking of Muslims grass root in Indonesia because many Islamic figures in Indonesian village are alumni of pesantren.

Therefore, examining whether the commitment of Muslim leaders in national level on democracy and plurality is supported by grass root particularly from pesantren leaders is the most significance of this study. In the mid of recurring extreme or radical movement in Indonesia, this study actually can be used as scholarly debate particularly to curb radical ideology from further entering pesantren.

Overall the study found that pesantren commitment to democracy still high. But, although they agree that democracy is compatible with Islam, this study reveals that their acceptance to pluralistic state based on Pancasila still be questioned as evidenced by many pesantren leaders think it is impossible to built peace coexistence eternally with non Muslims or infidels and almost half of them supported theocratic caliphate carry out by radical group. 
Although many argued that pesantren promote tolerance and pluralism, nevertheless this study shows that some of their teaching tacitly supported violence act in the name of religion that will tarnished the effort of Indonesia to synchronize Islam, democracy and modernity. It means that many of them actually not wholeheartedly accepted democracy and pluralism. 


\section{References}

Abas, Nasir. (2006). Membongkar Jamaah Islamiyah: Pengakuan mantan Anggota. Jakarta: Grafindo.

An-Na'im, Abdullahi Ahmed. (1990). Toward an Islamic Reformation: Civil Liberties, Human Rights, and International Law, Syracuse, Syracuse University Press.

Azra, Azyumardi. (1-4 November 2010). Cultural Pluralism in Indonesia: Continuous Reinventing of Indonesian Islam in Local, National and Global Contexts. Islamic Studies Banjarmasin.

Constitutional Court Verdict. (12 Agustus 2008). No. 19/PUU-VI/ 2008.

Dijk, C.Van. (1987). Rebellion Under Banner of Islam (The Darul Islam in Indonesia) translated Darul Islam: Sebuah Pemberontakan. Jakarta: Grafitipers.

Eksekusi Rajam Untuk Penzina di Ambon. http://www.oocities.com/arumbaikole/gatra040501.htm?20104.

Gatra No. 24. (30 April 2001). http://www.oocities.com/arumbaikole/gatra040501.htm?20104.

Khan,Qamaruddin. (1987). Political Concepts in The Qur'an, translated to Tentang Teori Politik Islam, Bandung: Pustaka.

Lev,Daniel S. (1990). Hukum dan Politik di Indonesia: Kesinambungan dan Perubahan (Law and Politics in Indonesia: Continuity and Change). Jakarta: LP3ES.

Mahmood, Tahir. (1987). Personal Law in Islamic Countries: History, Texts and Comparative Analysis. New Delhi: Academy of Law and Religion.

Nasution, Harun. (1985). Islam dan Sistem pemerintahan Sebagai yang Berkembang dalam Sejarah dalam Studia Islamika, Nomor 17 tahun VIII (July 1985). LP IAIN Syarif Hidayatullah Jakarta.

Nurrohman. (2007). Syari'at Islam, Konstitusi dan HAM. Bandung: Pustaka al-Kasyaf.

Nurrohman and Fisher Zulkarnain. (2007). Pesantren Gontor di Pentas Nasional; Potret Sejarah dan Pemikiran Alumni Pesantren Gontor (Gontor Pesantren at National Stage; History dan Thought of Gontor Alumni). Bandung: Malindo Institute.

Nurrohman. (2007). Konsep Imama: Studi atas Pemikiran al-Haramain, (The concept of Imama; Study of al_Haramain Thinking). Bandung, Pustaka al-Kasyaf.

Praja, Juhaya S. (2009). Teori-teori Hukum Islam. Bandung: Pasca Sarjana Universitas Islam Negeri (UIN).

Sjadzali, Munawir. (1990). Islam dan Tata Negara. Jakarta: UI Press.

Steenbrink, Karel A. (1986). Pesantren Madrasah, Sekolah, Pendidikan Islam dalam Kurun Modern, Jakarta: LP3ES. 
Suhartono. (7 Oktober 2010). KONFIGURASI POLITIK DAN LEGISLASI HUKUM ISLAM DI INDONESIA (Suatu Kajian tentang Positivisasi Fikih Muamalah dalam Perspektif Politik Hukum). http://www.badilag.net/data/ARTIKEL/WACANA HUKUM ISLAM/KONFIGURASI politik dan legislasi.pdf.

Suhartono. Konfigurasi Politik dan Legislasi Hukum Islam di Indonesia (Suatu Kajian tentang Positivisasi Fikih Muamalah dalam Perspektif Politik Hukum).

Surga Bukan Monopoli Muslim (Asghar Ali Engineer). (16 Oktober 2012). http://antimui.wordpress.com/2008/08/20/208/.

Syamsuddin, Din. (2006). The Role of Religions in Promoting Intercultural Understanding Toward Sustainable Peace. International Seminar hosted by the International Center for Islam and Pluralism (ICIP) and Finland Embassy Jakarta.

Wahid ed. Abdurrahman. (2009). Ilusi Negara Islam: Ekspansi Gerakan Transnasional di Indonesia. Jakarta: The Wahid Institute.

Watt, W.Montgomery. (1961). Muhammad Prophet and Statesman. Oxford: Oxford University Press.

Zein, ed., Kurniawan. (2001). Syari'at Islam Yes Syari'at Islam No, Dilema Piagam Jakarta dalam Amandemen UUD 1945. Jakarta: Paramadina.

www.crisisgroup.org 